This item was submitted to Loughborough's Research Repository by the author.

Items in Figshare are protected by copyright, with all rights reserved, unless otherwise indicated.

\title{
Establishing and weighting decision criteria for building system selection in housing construction
}

PLEASE CITE THE PUBLISHED VERSION

http://dx.doi.org/10.1061/(ASCE)C0.1943-7862.0000543

\section{PUBLISHER}

(c) American Society of Civil Engineers

\section{VERSION}

AM (Accepted Manuscript)

\section{PUBLISHER STATEMENT}

This work is made available according to the conditions of the Creative Commons Attribution-NonCommercialNoDerivatives 4.0 International (CC BY-NC-ND 4.0) licence. Full details of this licence are available at: https://creativecommons.org/licenses/by-nc-nd/4.0/

\section{LICENCE}

CC BY-NC-ND 4.0

\section{REPOSITORY RECORD}

Pan, Wei, Andrew R.J. Dainty, and Alistair G.F. Gibb. 2019. "Establishing and Weighting Decision Criteria for Building System Selection in Housing Construction”. figshare. https://hdl.handle.net/2134/17793. 


\title{
Establishing and weighting decision criteria for building system selection
}

\section{in housing construction}

\author{
Wei Pan $^{1}$, Andrew R. J. Dainty ${ }^{2}$ M.ASCE and Alistair G. F. Gibb ${ }^{3}$
}

\begin{abstract}
A lack of value-based decision criteria leads to an inability to effectively compare prefabrication and offsite production with conventional construction, which inhibits the realization of benefits of offsite approaches. This paper develops value-based decision criteria and quantifies their relative importance, for assessing building technologies systematically. The research employed a multi-methodological strategy within a broad case-study based design, with six large housebuilding organizations in the UK. These companies together accounted for over a tenth of new-build homes completions in the UK. Over fifty criteria were developed, grouped under cost, time, quality, health and safety, sustainability, process, procurement, and regulatory and statutory acceptance. Cost was ranked most important, which, coupled with time and quality, predominated technology selection in these companies. Sustainability, process and procurement were weighed lower, while health and safety and regulatory and statutory acceptance were deemed compulsory, hence offering no trade-off opportunity. A lack of incorporating innovative sustainable technology into corporate strategy is observed. The developed criteria and the systematic process should help housebuilding organizations manage technological innovation and hopefully achieve more informed corporate decisions.
\end{abstract}

CE Database subject headings: Prefabrication; Construction methods; Construction management; Decision making; Residential housing; United Kingdom; Offsite production; Decision criteria.

\footnotetext{
${ }^{1}$ Reader, School of Architecture, Design and Environment, University of Plymouth, Plymouth, Devon, PL4 8AA, UK Email: wei.pan@plymouth.ac.uk

${ }^{2}$ Professor, Department of Civil and Building Engineering, Loughborough University, Loughborough, LE11 3TU, UK Email: a.r.j.dainty@lboro.ac.uk

${ }^{3}$ Professor, Department of Civil and Building Engineering, Loughborough University, Loughborough, LE11 3TU, UK Email: a.g.gibb@lboro.ac.uk
} 


\section{Introduction}

In recent years, construction technology has evolved from conventional site-based methods to a more dynamic combination of methods involving a greater use of offsite production technologies, industrialized techniques and systematic building philosophy (see e.g. Gibb 1999; Girmscheid and Scheublin 2010; Gann 2000; Gann and Senker 1993). Such evolution features terms such as offsite production and 'modern methods of construction' (MMC) in the UK (see Pan et al. 2007), and 'Prefabrication, Preassembly, Modularization, and Off-site Fabrication' (PPMOF) (Tatum et al. 1987) or collectively termed as 'prework' (Song et al. 2005) in the US. Evidence of this paradigm shift across the world is also supported by the growth in prefabricated house building in Japan (Barlow and Ozaki 2005), offsite manufactured housing in Germany (Venables and Courtney 2004), industrialised building in Malaysia (Kadir et al. 2006), offsite manufacture in Australian construction (Blismas and Wakefield 2009), and prefabricated high-rise residential developments in Hong Kong (Tam et al. 2002; Jaillon and Poon 2009).

The evolution of construction technology inevitably leads to a rapidly increasing market for supplying offsite technology and innovative building systems. In the UK, there are over 100 reported offsite production systems being supplied by over 570 manufacturers and suppliers (Mtech Group 2007). This market is likely to expand given the significant demand for new-build homes (DCLG 2007) and the UK government promotion of offsite for improving quality and efficiency of housing supply (ODPM 2003; DCLG 2006; HCA 2010), albeit such promotion has become less overt following the economic recession and the government spending review process (TSO 2010). The policies on environmental sustainability, markedly focusing on the implementation of the 'Code for Sustainable Homes' (CfSH) and the UK’s national target of achieving 'zero carbon homes' by 2016 
(DCLG 2007), encourage the optimization of offsite production (Osmani and O’Reilly 2009). However, the take-up of offsite technology in UK housing is still low (Pan et al. 2008) and the full benefits of offsite production approaches are not realized in many cases. The low take-up of prefabrication has also been reported in the precast concrete industry of North America, with its market share at 1.2\% (Sacks et al. 2004). Late decisions on adopting offsite technology are often made by stakeholders including clients (Gibb and Isack 2003), housebuilders (Pan et al. 2008) and their professional advisors (Monjo-Carrio et al. 2010), which was also revealed in a recent offsite market survey (Goodier and Gibb 2007). Such practice often appears to be ascribed to a risk-averse culture in industry and housebuilders’ propensity to reduce perceived financial risks associated with making early commitment to innovative technology (Callcutt 2007). However, an arguably more important factor is the inability of decision-makers to effectively compare offsite with conventional methods or partiality in their decision-making, which are attributed to a lack of value-based decision criteria and ineffectiveness of obtaining information on different types of building systems at early design stages.

This paper aims to address this knowledge gap by developing technology selection decision criteria which enable the assessment of building technologies systematically and effectively. The term 'building system' is used in this paper to encompass all such construction technologies with a focus on prefabrication and offsite production. By using this term, a systematic approach is advocated for value-based comparison between offsite and conventional building systems, rather than evaluation of building components per se which often ends up as a cost comparison exercise. Two housing types were used for the investigation: houses and low-rise multi-occupant apartment buildings, which represent the primary home building practice in the UK. Houses account for $82 \%$ of dwelling stock in 
England (DCLG 2010), while the split between houses and flats in new-build in recent years has presented a trend towards equilibrium, reaching 50/50 in 2008/2009 (DCLG 2010). Despite the fast growth of high-density smaller one and two-bedroom flats within individual blocks in the first decade of this millennium, high-rise apartment buildings are very unlikely to attract future attention of both supply and demand sides following the economic downturn (Knight Frank 2009). The research was carried out within the context of large housebuilding organizations which, as a whole, build more than two thirds of all new homes in the UK (Wellings 2006). Most of these firms operate on the 'current trader' business model (CallCutt 2007), or 'classic private housebuilder' business model as referred to by Ball (2010), e.g. eliciting profits more from land acquisition and development than from the actual construction process itself (Meikle 2008). On such a business model, the organizations normally adopt some standard house types and maximize design standardization and repeatability, which helps improve business efficiency. However, when challenged or encouraged to take up innovative sustainable technology (e.g. under the CfSH scheme), the firms are exposed to both technical and business risks. It is therefore important to provide decision support to housebuilding organizations for assessing innovative technology. The paper explores the decision criteria for building system selection and quantifies their relative importance drawing on the perspective and practice of a leading UK national housebuilder. It then verifies the criteria and their weights within the context of five other large firms. The implications of the results are discussed, which leads to conclusions about construction technology selection on an organizational level. 


\section{Building system selection: decision criteria}

\section{Value-based approach?}

The practice of construction technology evaluation and selection has been widely studied. Wells (1993) assessed the success of appropriate building technologies in three projects in meeting client expectations in terms of time, cost, quality and broader economic implications. However, this evaluation was largely qualitative, and trade-offs, if considered at all, between the performance measurements of the technologies was unclear. Tam et al. (2002) evaluated the impact of utilizing three different construction methods on production in high-rise residential building. Their evaluation, albeit useful, drew on three specific criteria only, i.e. duration of structural frame construction, labor input and costs for direct labor and plant, hence offering limited decision guidance for selecting building systems, particularly in the organizational context. Kadir et al. (2006) compared construction performance in relation to labor productivity, construction structural cost, crew size and cycle time between conventional and industrialized building systems. Despite the attempt to quantify the relationships between the measurements, their findings failed to distinguish between industrialized and conventional systems, but led to fragmented interpretations of the technological solutions.

With an increasing emphasis on more balanced technology decision-making, Birkbeck and Scoones (2005) suggested that criteria like cost, supply, technical considerations and building height play an important part in helping designers and builders decide the most appropriate structural form. Aesthetics, however, are rarely a consideration, as the structural systems are seldom expressed as part of the overall external presentation of the buildings. The availability of materials could be another criterion for building system selection, as argued by Prewer (2005) who claimed that steel structures provide greater 
resource efficiency than concrete or all-timber structures. Pasquire and Gibb (2002) reported that decisions to use offsite were largely based on anecdotal evidence rather than rigorous data as no formal measurement procedures or strategies were available. Blismas et al. (2006) presented further evidence demonstrating that decisions to compare traditional and offsite technological solutions for construction in general were largely based on material, labor and transportation costs, whilst other cost-related items such as site facilities, crane use and rectification of works were disregarded or buried within the nebulous preliminary cost items, and softer issues such as health \& safety, effects on management and process benefits were either implicit or disregarded. The industry, as a whole, still sees a fragmented cost-driven, rather than systematic value-based, decision culture prevailing in construction technology evaluation and selection practice.

\section{Reflecting organizational contexts?}

Recent research (Chen et al. 2010) found that, although time and cost remained as the most important criteria for choosing a construction method, social awareness and environmental concerns were considered to be increasingly important. The increasingly stringent regulations and standards on sustainability (see e.g. Atkinson et al. 2009) push outwards the boundary of construction technology selection criteria which were mainly associated with quality, cost and time conventionally. The varied environmental performance assessment methods, e.g. BREEAM and CfSH in the UK and their counterparts worldwide, are particularly re-shaping the decision thinking of housebuilders and homebuyers (see e.g. Kim et al. 2005; Osmani and O’Reilly 2009). Although multiple criteria have been used for assessing construction systems and methods, they are largely constrained to technical processes from designers’ perspectives (see e.g. Nassar et al. 2003) and/or construction processes (see e.g. Idrus and Newman 2002; Rogers 2000). Soetanto et al. (2004) provided 
a list of criteria for structural frame selection, drawing on existing knowledge and perspectives of wide-ranging practitioners including clients, designers and contractors. This list of criteria contributes to achieving a more objective and systematic frame selection by the project team, but is focused on 'hybrid concrete construction' (i.e. 'highly innovative combinations of in situ and precast concrete elements') only and lacks an input of the organizational business context, e.g. criteria on supply chain management and acceptance of insurers and financers. These organizational business criteria are too significant to decision-making in technology selection in housebuilding to be implicit or overlooked. This significance was highlighted in a recent survey of large UK housebuilders (Pan et al. 2008) which reveals that the housebuilders assessed the potential for offsite-MMC applications against a wide range of factors including technical requirements, cost, time, site integration and logistical concerns, customer choice options, sales impacts, mortgage issues, and site constraints.

Blismas et al. (2006) suggested that a wider account of value-based measures including quality, health, safety, sustainability, and logistics as the means of broadening the comparative exercise from the one-dimensional cost basis to a multi-dimensional valuebased system. However, decision criteria derived on a value-laden basis have relative and context-specific features. Stakeholders from different parties of the project team may have different perceptions and aspirations of the use of innovative construction approaches. Such dynamic and complex decision-making context is not unusual in housebuilding, which normally involves a wide range of stakeholders at industrial and intra- and interorganizational levels (see Pan et al. 2007). 


\section{General observations on the knowledge gaps}

The review above allows three general observations. First, despite the many previous studies of construction technology evaluation and selection, the selection criteria used reflect little on the value approach. Also, many criteria examined in previous research are presented in generic terms with little or no explanation and therefore may be mutually interactive and consequently render the reliability of the evaluation questionable. Secondly, how the decision criteria are addressed in specific housebuilding organizational or project contexts appears nebulous or overlooked. There is a lack of strategic thinking of innovative technology selection at the corporate level. Thirdly, a direct comparison between offsite produced and conventional insitu products is not usually possible and would also be less meaningful, given the complexity of, and interactions between, building elements and their associated trades and resources. A systematic approach is needed for housebuilding organizations to identify value-based criteria and establish their relative importance to achieving decision objectives. The knowledge gaps suggested in these observations are addressed in this paper.

\section{Methodology}

\section{Research design}

This research employed a multi-methodological strategy within a broad case-study based design (see Yin 2003). An initial literature review examined the attributes and criteria explored in previous research for comparing offsite production with conventional construction methods. This review enabled the development of a conceptual decision criteria framework. Six case studies were investigated as a two-stage process comprising an exploratory case and five verification cases. The initial case study involved a leading housebuilder and was partly action research in which the researcher made contributions to 
understanding the process of establishing and weighting decision criteria and developing strategies for achieving effective building system selection in the company based on the diagnosis of their practice (Bryman 2008). The results were then verified using the five follow-up case studies with other housebuilding firms. This two-stage case study research design for examining decision criteria for building system selection is innovative, as it moves towards a more critical direction to address the value-laden and context-specific features of technology decision-making, from the survey-based approach which seems to dominate decision criteria related research to date. The use of the survey-based approach for technology selection research, e.g. construction method selection in concrete buildings by Chen et al. (2010) and selecting intelligent building systems by Wong and Li (2008), is useful to identify a broad perspective of practice on selection criteria, but hardly offers indepth exploration of underlying considerations for the decision. Indeed, research into technology selection will lose value if it is isolated from organizational and project specifics. However, the case study approach is more appropriate for exploratory research addressing 'why' and 'how' questions (Yin 2003). The case study approach is often applied in organizational studies, for instance, of re-engineering the construction process in UK speculative house-building by Roy et al. (2003), matching supply networks to Dutch modular house-building by Hofman et al. (2009), and managing technological innovation and processes of Swedish building component manufacturers by Larsson et al. (2006). In this present study, the six case studies together aimed to contextualize, verify and expand the conceptual decision criteria framework developed from the review of existing knowledge. 


\section{Participating organizations}

The six organizations (referred to in this paper as Companies A-F) used for the case studies were selected from the large housebuilders in the UK (see Welling 2006). All the firms were prominent industry players and had used offsite technologies extensively for their housing projects. The integration of the offsite approach to their build processes had been taken on board within all the companies. The selection of the organizations used a 'convenience sampling’ strategy (Bryman 2008), as these firms expressed interest in participating in the study and provided access to information. Out of these organizations, Company A was selected for the initial case study for two reasons. It was a leading UK national housebuilder, committed to developing sustainable communities and open to the utilization of innovative and modern methods of construction in pursuit of this corporate objective. It aspired to improve business efficiency by standardizing design processes which involved investigations into the use of offsite, and sought to learn from their experience. The other reason was that Company A allowed sustained, long-term access required to undertake the work (Silverman 2005). The six housebuilding organizations together contributed over $10 \%$ of new-build homes completions by the UK industry as a whole (Table 1). Such representation of industry practice may not fully satisfy the quantitative sampling principle. However, the nature of the in-depth case studies with the organizations should provide logic of replication of selecting building systems in housebuilding.

\section{[Insert Table 1 here]}

\section{Data collection and analysis}

The most regularly-built building types of each participating company were focused on for data collection, and they were houses and low-rise multi-occupant apartment buildings

(Table 2). The most used or considered building systems included traditional brick \& block, 
thin-joint masonry, open timber panel, closed timber panel, insitu reinforced concrete frame, precast concrete crosswall, steel frame with precast floors and steel framed modular building (Table 2). Such focus enabled the 'best' reflection of primary building practice in these organizations, i.e. enhancing the validity of data collected, and also addressed the time constraint on the study, i.e. ensuring the practicality of data collection. The identified building types and building systems of the companies overlapped with each other, which enabled effective comparison between the results (Table 2).

[Insert Table 2 here]

The initial case study with Company A contextualized the use of the conceptual decision criteria framework for selecting building systems. This case study started with semistructured interviews with the senior managers covering the roles including technical, design, sustainability, estimating and business consultancy (Table 1) who were perceived to have significant influence on building system selection in the organization. These interviews aimed to explore the business context, decision objectives and practice of the company in relation to the selection of offsite technology. A one-day workshop was then run with the senior managers, in which the participants were asked first to examine a process of establishing decision criteria for building system selection, and then to weigh the established criteria drawing on their experience and expertise. The resultant weights were also discussed and verified by all the participants. The results from the initial case study were then examined through case studies with the five other housebuilders (Companies B-F). Each of the follow-up case studies involved document analysis and an interactive workshop with the senior directors or managers of these companies (Table 1). The identified decision criteria, in the structure of a 'value tree' (see Keeney and Raiffa 1976), were presented and explained to the workshop participants for comments. The 
verified decision criteria were weighed by the participants within the context of their primary building types (Table 2). Through these workshops, the decision criteria were explored from a wider housebuilding business perspective. All the participants were involved in decision-making for selecting building systems in their organizations. The participants from five companies had been involved in at least one UK government-backed offsite/modern methods initiative, some taking the role of chairing their study groups. The other company had been heavily involved in the manufacturing industry and was exploring their offsite applications at the time of the study.

Weighting methods and techniques abound in literature. Typical examples include the multi-attribute utility theory (Keeney and Raiffa 1976), the Simple Multi-Attribute Rating Technique (SMART) (Edwards 1977) and its refined versions SMARTS (SMART using Swings) (Edwards and Barron 1994) and SMARTER (SMART Extended to Ranking) (Barron and Barrett 1996), the surrogate weighting methods, the direct rating methods, either Bottom-up Direct Rating (BDR) or Top-down Direct Rating (TDR), the Point Allocation (PA) method (Roberts and Goodwin 2002), and the Analytical Hierarchy Process (AHP) (Saaty 1980). All these methods have been regarded as effective in some contexts but criticized in others. For perceived simplicity and easy application the methods TDR, BDR, PA and AHP were presented and explained to the participants. The participants were provided with the flexibility of selecting any combination of the methods that they would feel most comfortable and appropriate to use for weighing decision criteria. The provision of this flexibility aimed to enhance practicality of data collection, ensure validity of data, enable effective comparisons between results obtained by using different methods, and refine the weighting methods if necessary. The data collected is qualitative in relation to decision criteria and quantitative regarding the weights. The 
qualitative data was analyzed using the content analysis method, following the process of coding, identifying themes and developing patterns (Patton 2002). The quantitative data was stored and analyzed using Microsoft Excel.

\section{Criteria development and weighting}

\section{Decision criteria: Initial development (Company A)}

A wide range of decision criteria were identified from the literature review in relation to the adoption and selection of offsite production technology. The many decision criteria were grouped under thematic subheadings which were further categorized into eight headings including cost, time, quality, health \& safety (H\&S), sustainability, process, procurement, and regulatory and statutory acceptance (see Table 3). This conceptual framework was examined in the initial case study with Company A.

[Insert Table 3 here]

A 5-step process drawing on the procedures provided by Dodgson et al. (2000) for multicriteria analysis was used for establishing and examining decision criteria. Firstly, the industry and corporate decision contexts were clarified for establishing decision criteria. At the industry level, examples of important contexts included the annual targets of performance improvement in construction recommended by Egan (1998), the KPIs for new-build homes established by Constructing Excellence (2004), the drivers for and constraints to standardization and preassembly provided by Gibb and Pendlebury (2005), and the drivers and barriers to the use of offsite-MMC identified from leading housebuilders (Pan et al. 2007). The performance indicators for assessing MMC suggested by NAO (2007) and the benefit evaluation framework for offsite production presented by Blismas et al. (2006) also helped clarify the industry context. At the organizational level, 
the housebuilder considered a variety of criteria in order to satisfy their customers and elicit long-term profitability, which were reflected in their corporate policy and company documents such as the 'Guide for Design' (an internal design management tool) and the 'Environmental, Social and Ethics Review'.

Secondly, the decision objectives were established. The 'ultimate objective' of Company A was to improve business efficiency and long-term profitability. The 'immediate objectives' included to increase design standardization, to benchmark good practices within the company, to reduce business risks, and to ensure time and cost certainties.

Thirdly, the decision criteria were identified, as a consequence of the clarification of the industry and organizational contexts and the establishment of the decision objectives. Over 50 criteria in total were generated. It would be extremely difficult and unwise to weigh such a large number of criteria at the same level.

Fourthly, the criteria were therefore clustered, drawing on the categories suggested in the conceptual framework grounded on the literature review. The same eight categories were considered appropriate to reflecting the key areas where the decision objectives were focused in the company. These categories were referred to as the key criteria at the objective level (or the first level) of the decision criteria matrix. The key criteria were broken down into more detailed second-level criteria, some of which were further broken down into sub-criteria at the third level.

Fifthly, all the criteria were assessed, drawing on the quality criteria provided by Dodgson et al. (2000) which include completeness, redundancy, operationality, mutual 
independence of preferences, double counting, overall number and changeability over time of the criteria. This 5-step process provides a systematic approach to establishing valuebased decision criteria for building system selection. It was regarded by the participants as effective and well-structured.

\section{Decision criteria: Verifications (Companies B-F)}

The decision criteria were presented and explained to the participants in the follow-up workshops with the other five housebuilders. All the participants commented that the objectives, main criteria and the hierarchy illustrated the current industry concerns over the use of offsite effectively and comprehensively. The participants also provided some extra factors for consideration and/or made minor modifications to the criteria and sub-criteria in order to reflect the practice of their companies. Most of the extra factors provided were actually covered under criteria with slightly different terminologies, but some supplemented the original thinking and, thus, were taken on board for refining the decision criteria matrix. This refining process expanded further the coverage of the decision criteria and enriched their practicality.

The 5-step process was confirmed in the follow-up workshops, and the participants considered the top-down approach as appropriate for the case of selecting building systems as there already existed overall performance objectives in industry and benchmarking KPI targets in their businesses. The discussion with the participants suggested that the decision criteria and the process could help housebuilding organizations in a number of aspects: 1) structure the thinking of selecting appropriate building systems for specific projects, 2) clarify the value management structure of the organization, 3) provide a checklist of 
collecting 'what' information from 'where' and by 'whom', and 4) present a framework for measuring the performance of offsite technology.

\section{Weighting decision criteria (Company A)}

Due to the participants’ availability, the individual weighting in Company A was undertaken through a face-to-face interview with the Group Technical Manager and a workshop with the three other key roles including the Architect, the Engineer and the Estimating Director (Table 1). The Group Technical Manager chose to use Top-down Direct Rating (TDR) for weighting the eight objective-level criteria. The original ratings obtained were normalized to generate weights. The results show that the weights of the objective-level criteria ranged from 15\% (cost) to 11\% (time as well as sustainability), which suggests that the Group Technical Manager took all the eight key criteria into consideration for building system selection and attempted to maintain a balanced perspective on them. For weighting the criteria at the second and third levels of the decision matrix, the Group Technical Manager chose to use the combination of TDR and Point Allocation (PA).

In the workshop, the three other participants were asked to weigh the criteria, on an individual basis, using the Analytical Hierarchy Process (AHP) by completing the provided pair-wise comparison questionnaires. The weights were the 'normalized eigenvector values’ obtained by calculating the 'Geomean' of the AHP scores (see Saaty 1980 for detailed instructions), using a program designed by the researcher but based on the functions provided in Microsoft Excel. The consistency ratios for the AHP scores provided by the participants were calculated using the method of eigenvector values. The results show that the consistency ratios for the AHP scores for the first-level criteria from all the 
workshop participants exceeded the value allowed, i.e. > 0.1 (Saaty 1980), which reveals that the participants' answers to the pair-wise comparison questions were not consistent and therefore logically invalid. In order to enhance the consistency and obtain ‘triangulation’ of results, the participants were asked, as a group, to weigh the criteria again. This group exercise was carried out using the AHP calculation forms presented on the screen of a computer, facilitated by the researcher. All the participants had to agree on the AHP scores and make sure the consistency ratio of one group of criteria below 0.1 before moving to another. The weights obtained were then verified by the group. There was no statistically significant correlation between the weighting results from the four participants obtained on an individual basis. The correlations appear more statistically significant between the group-agreed weights and the individually obtained weights, of objective-level criteria, from the Estimator ( $r=0.700, p=0.053$, 2-tailed) and the Group Technical Manager ( $r=0.612, p=0.107$, 2-tailed). At the bottom level of the decision criteria matrix, a modest positive correlation ( $r=0.030, p=0.060$, 2-tailed) was observed between the weights agreed by the group and provided by the Group Technical Manager.

Considering the consistency ratios and correlation profiles, the set of group-agreed weights were regarded as most closely to reflect the decision-thinking for building system selection in Company A. The decision-thinking was apparently cost-driven (34\%), but taking into account all the key objectives including process (23\%), regulatory \& statutory acceptance (14\%), time (8\%), quality (7\%) and procurement (7\%). H\&S (4\%) and sustainability (4\%) criteria were regarded important but weighed lower as they were considered mostly related to regulations and legislations and therefore were compulsory to comply with. However, the 'triangulation' of the weighting results suggests the complexity of the decision-making 
exercise and the inconsistency among the decision-makers in eliciting the relative importance of the many criteria.

\section{Weighting decision criteria (Companies B-F)}

The workshop participants, after being briefed on the use of the weighting methods Topdown Direct Rating (TDR), Bottom-up Direct Rating (BDR), Point Allocation (PA) and Analytical Hierarchy Process (AHP), chose to use TDR (Companies C and E) or PA (Companies B, D and F), but not AHP or BDR, for perceived simplicity and personal preference.

In the case of houses, the weights of the criteria at the objective level from the four companies (B, C, D and F) were compared with each other. Cost was clearly the most important decision criterion taken by all these housebuilders, particularly significant by Companies B and F (both at 60\%) (Figure 1). The criteria of time, quality, process, procurement and sustainability were weighed no heavier than $20 \%$ by all the participants. All the four companies took the criterion of 'regulatory and statutory acceptance' out of their weighting exercise (with $0 \%$ weight, Figure 1) because they regarded it as compulsory and fundamental and commented that no housing would be built if it was unacceptable to regulatory and statutory authorities. Similarly, all the companies did not consider H\&S, except for Company F who weighed it very low (1\%), because they considered H\&S important but compulsory so that all related H\&S regulations should be satisfied no matter what building systems are selected. Companies C and D weighed the remaining criteria quite similarly, and emphasized that all criteria were interrelated and should be taken into account without mutual compromise.

[Insert Figure 1 here] 
The weights obtained from Companies B and F (both with $s=20 \%$ ) were more variable than those from Companies $\mathrm{C}$ and $\mathrm{D}$ (both with $s=0.08$ ). The weights of the decision criteria at the objective level from Companies B and F were strongly positively correlated ( $r=0.975, p<0.001,2$-tailed). A similar correlation existed between the weights from Companies C and D ( $r=0.947, p<0.001$, 2-tailed). No other correlations were observed between the weighting results at the $p<0.1$ level.

The cost criteria weights ( $s=23 \%$ ) were more variable than any of the non-cost criteria weights $(s \leq 8 \%)$. The analysis of the case of houses in Companies B, C, D and F also reveals a strong negative linear correlation between the weights of cost and process criteria ( $r=-0.992, p<0.01$ ), and strong linear correlations between the weights of cost and time criteria ( $r=-0.945)$, of cost and procurement criteria $(r=-0.912)$, of time and process criteria $(r=0.901)$, and of sustainability and process criteria $(r=0.907)$ at the $p<0.1$ level. Although the statistics help explain how the key criteria varied against each other, the small number of datasets available should be taken into account when interpreting the results.

In the case of low-rise apartment buildings, the weights of the criteria at the objective level from three companies (A, E \& F) were compared with each other. Company F, again, regarded cost as predominant (50\%) but thought of time to be much more important for apartments (15\%) than for houses (4\%). Company E weighed all the criteria more evenly, within the range from $9 \%$ (process, procurement as well as regulatory \& statutory acceptance) to $17 \%$ (time) (Figure 2). The weights obtained from Company F ( $s=0.16$ ) were more variable than from Company A $(s=0.06)$ and Company E $(s=0.03)$. A strong 
positive linear correlation was observed between the weights from Company A (groupagreed) and $\mathrm{F}$ ( $r=0.729, p=0.040,2$-tailed). Comparing the weight profiles of the two building types suggests a more balanced decision-making of the practices for low-rise apartment buildings (Figure 2) than for houses (Figure 1).

[Insert Figure 2 here]

The weights of the criteria at the second and third levels of the decision criteria matrix were also obtained through calculations, which, coupled with the main criteria weights, provide an overall perspective of the six large housebuilding organizations on the decision criteria for construction technology selection (Table 3). For the case of houses, positive correlations were found as strong between the weights from Companies B and F ( $r=$ 0.882) and that from Companies $\mathrm{C}$ and $\mathrm{D}(r=0.848)$, and as modest between the weights from Companies B and C ( $r=0.578)$ and that from Companies C and F ( $r=0.499)$, all at the $p<0.01$ level (Table 4). These results support the patterns observed between the weighting results at the objective level (Figure 1). For the case of low-rise apartment buildings, only modest correlations were identified between the weights from Companies A and F ( $r=0.464, p=0.007)$, followed by that from Companies $\mathrm{E}$ and $\mathrm{F}(r=0.359, p=$ 0.025) (Table 4). Comparing the correlation profiles suggests more varied perspectives of housebuilders on technology selection for apartment buildings.

[Insert Table 4 here]

The discussion with the workshop participants also generates several observations on their decision thinking and practice. First of all, different housebuilding business models possess different impacts on weighting the criteria. Time criteria were considered more important for apartment construction than for house building and more significant for the case of 
social housing than for private developments. The housebuilders were mainly concerned with addressing different financial structures of the projects and achieving a match between the speed of build and the rate of sales. Also, it was suggested that the non-cost criteria could be weighed against their impacts on cost terms. However, it was argued that it might be difficult to quantitatively measure performance of building systems against the non-cost criteria, e.g. quality, sustainability and regulatory acceptance. Therefore, qualitative measurements were needed as a useful complement to quantities. Further, the participants commented that some criteria were interrelated, e.g. established long-term supply chains standardize business processes, and improvements in processes lead to reducing costs and speeding up construction program. An implication of such interactions is that the criteria must be clearly defined and explained in order to elicit effective weights.

\section{Discussion}

\section{Decision criteria}

The decision criteria established through this study attempted to address the knowledge gaps identified in the literature review, i.e. little transparent consideration for housebuilding organizational or project contexts and little reflection on value in a systematic approach. At the macro level of the decision matrix, the criteria embed the conventional, high-profile concepts of cost, time, quality and health \& safety, and also cover sustainability and regulatory \& statutory acceptance which are increasingly important (Atkinson et al. 2009; Chen et al. 2010). Further, process and procurement criteria are included, which are more related to the business context of housebuilding organizations. The results of contextualizing all these main criteria into the six housebuilding organizations verified their practicality and effectiveness. Most participants, however, claimed that the criteria at the macro level were interrelated with each other. 
Therefore, use of these high-level criteria per se could lead to implicit or imbalanced weights and inconsistent measurements of performance of building systems. Such weakness is evidenced in some previous research (e.g. Wells 1993; Kadir et al. 2006). Consequently, the eight main objectives were broken down into more detailed, workable criteria, for which explicit definitions were also provided in the organizational contexts. This is illustrated at the micro levels of the decision matrix which includes over 50 criteria and sub-criteria. Nevertheless, these detailed-level criteria were largely addressing conventional decision concerns such as cost, time, quality, process and procurement, whilst the firms’ appreciation of sustainability and regulatory requirements for building system selection was still insufficient and fragmented.

The results reveal that the organizations preferred a structured process of establishing decision criteria, in order to enhance value in their future practice. As illustrated in the case studies, such a process includes five steps: clarify decision context, establish decision objectives, identify decision criteria, cluster criteria and assess criteria. This process is in a logical agreement with, but simplifies, the multi-criteria decision analysis procedures (see Dodgson et al. 2000). The first two steps of the process incorporate organizational context and corporate objectives into construction technology selection. These activities should help the decision-maker start to consider offsite construction solutions strategically from land acquisition or outlined design stages, rather than until detailed design or preconstruction stages which however existed in many housebuilders' practices (Pan et al. 2008). The former practice more likely leads to integrated supply chains and optimized design and production processes, whilst the latter practice often misses opportunities of realizing value of prefabrication and ends up with cost-based comparison of building methods. The three-level decision criteria matrix, coupled with the five-step process of 
establishing criteria, provides a systematic approach to assessing building systems. This approach was confirmed by the participating companies, which were key industry players, to be an effective mechanism for improving value-based technology selection practice at an organization level. This perspective is supported by Dodgson et al. (2008) who suggested that technological innovation management should form part of the corporate strategy for driving organizational competitiveness. The systematic use of the decision criteria should help organizations collect more transparent information of building systems for achieving more informed decisions and enhancing management auditability and transparency. It will also enable demonstrating the benefits of offsite production over conventional construction, which will hopefully encourage a wider take-up of offsite technology and promote a value culture in industry.

\section{Relative importance of decision criteria}

All the eight key objective-level decision criteria were claimed as very important and no one should be left out of the decision-making equation for building system selection. This indicates housebuilders' awareness of wide-ranging factors for technology assessment, which reflects the dynamic and balanced performance measurement and decision practice promoted in the few UK government/industry initiatives (e.g. Constructing Excellence 2004; Gibb and Pendlebury 2005; NAO 2007).

Nevertheless, the weighting outcomes from the case studies indicate that cost was considered as the most important decision criterion for building system selection. This result is consistent with the findings from the housebuilder survey by Pan et al. (2007) that ensuring cost certainties was an important driver for utilizing offsite technology and that higher costs associated with offsite production, either real or perceived, were the most 
significant barrier against its take-up. The result also reflects the general industry perception that housebuilding by offsite is more expensive than by traditional construction methods (Birkbeck and Scoones 2005), and supports the finding of a positive correlation between building construction costs and the proportion of openings and prefabricated façade areas of external walls (Stoy et al. 2008). Given the typical cost-driven decision philosophy prevailing in the industry (Wood and Ellis 2005), it is understandable that the housebuilders weighed cost criteria most heavily. Some researchers (Blismas et al. 2006) have argued against this ‘cost myth’ and suggested developing rigorous methods for measuring the value of offsite. Some tools are available (see Chen et al. 2010), e.g. 'IMMPREST' (Interactive Method of Measuring Pre-assembly and Standardization Technique) which provide a structured, value-based approach to technology assessment (Pasquire et al. 2005) and the ‘Strategic Decision Tool’ for PPMOF (Song et al. 2005). However, it is not clear how the relative importance of the decision criteria is derived in these studies and also further work is needed to transfer the knowledge for use in the housing sector. More significantly, a value-based decision culture should be nurtured in the housebuilding industry for innovative technology selection.

The results show that time criteria were also weighed heavily, which aligns with the UK government's call for building homes more quickly and efficiently using MMC (NAO 2005) in addressing the under-supply of housing. Such results correlate to the higher productivity of construction from offsite production over on-site activities in the US (see Mullens and Arif 2006; Eastman and Sacks 2008). However, the drive for speed has been diluted, particularly for building houses, with the economic recession. There also existed varied interpretations of the importance of time criteria in relation to different business and project contexts. Typical examples identified included the driver for faster speed of 
construction for apartment buildings than for houses and the requirement for an early and certain completion of social housing dwellings than of private developments. These results support the claims of Callcutt (2007) and Ball (2010) about the different business models of UK housebuilders and their implications on building operations. The results also demonstrate the general aspiration of housebuilding firms to achieve a good match between the speed of building and the rate of sales as observed by Adams and Leishman (2008).

The criteria of H\&S and regulatory \& statutory acceptance were regarded by the participants as essential for selecting construction methods, which echoes the claim of prefabrication as the most promising method of fall prevention (c.f. Huang and Hinze 2003), and reflects the implications on housebuilding of the increasing concerns of the insurance industry and financial market with the housing built by using offsite (see BRE Certification 2005). However, these criteria were weighed zero or very low particularly for houses, as they were thought to be compulsory and should be complied with, no matter what types of building systems were adopted. In comparison, the sustainability criteria were generally weighed higher, but still at a lower level compared to the criteria of cost, time or quality. The benefits of adopting offsite prefabrication in sustainability, e.g. improved energy efficiency and reduced construction waste, although widely reported (e.g. Pan 2010; Tam et al. 2007; Blismas et al. 2006), were not well recognized in the housebuilders' decision thinking. These seemingly paradoxical perspectives suggest a lack of appreciation, or desire, of the housebuilders for achieving performance superior to regulatory and statutory requirements, which inevitably inhibits the realization of the full benefits from utilizing offsite technology. This result is also attributable to the voluntary nature of sustainability standards superior to building regulations and the implications of 
the market downturn. However, there is an increasing concern on environmental sustainability in the housebuilding market (OFT 2008) and a clear long-term policy focus on delivering sustainable homes and achieving zero carbon status (DCLG 2007). The importance of sustainability criteria, although being weighed low, is likely to rise up. There is therefore an urgent need for housebuilding firms to incorporate sustainability and the take-up of innovative sustainable technology into their business strategy, in order to mitigate risks and maintain competitiveness.

The results suggest two patterns of perspective on the relative importance of the key criteria, largely reflected in the different extents of weighing cost criteria. Some housebuilders weighed cost significantly higher than others did. Such differences appear to be attributed to the varied decision contexts, business objectives and practice between the organizations. All the weighting results were examined and confirmed by the participants in relation to reflecting their decision philosophy and practice, and therefore were considered valid. The participating companies together accounted for over $10 \%$ new-build homes completions in industry, so that the weights obtained from these companies (Table 3) provide a useful snapshot of the relative importance of the key criteria for building system selection in UK housebuilding. However, the weights from individual companies are not averaged, which might lead to biased or partial perspective, as the weights were company and practice specific. Also, the results are based on UK housebuilding which has a much higher degree of concentration than either Australia or the US (Ball 2008). The two associated reasons - market diversification and land planning dominance of large firms also contribute to low innovation in UK housebuilding. Such context may be different in countries where the linkages between contracting and housebuilding are closer and the decoupling of housebuilding from land acquisition is clearer (Meikle 2008). Therefore, it is 
the 'soft' paradigm to be logic of replication and of concern, rather than the repetition of quantitative sampling-based weights. Future research may identify perspectives on the weights of the decision criteria in a broader context, which should enable wider or more quantitatively evaluation of the results.

\section{Conclusions}

Drawing on a critical literature review and in-depth case studies with six UK large housebuilding organizations, this paper has established decision criteria, structured in the form of a three-level decision matrix, for comparing offsite with conventional construction methods. The decision matrix provides over 50 value-based criteria grouped under eight objectives including cost, time, quality, health \& safety, sustainability, process, procurement and regulatory and statutory acceptance. The organizations' perspectives on relative significance of the criteria were quantified, which yields interesting statistical correlations between the technology decision thinking of the businesses. Despite an increasing awareness of using more balanced criteria, technology selection in housebuilding was still cost-driven. Other criteria including time, process, quality and procurement were largely interpreted on financial terms, either implicitly or explicitly, suggesting room to explore value. Sustainability, health \& safety and regulatory and statutory acceptance criteria were regarded as important but compulsory, hence offering no or little trade-off in the decision equation. A lack of strategic thinking of incorporating innovative sustainable technology into organizational strategy was identified. Such practice exposed the businesses to significant risks given the increasing concerns about environmental sustainability and the government policy of achieving 'zero carbon homes' by 2016 in the UK. A process of establishing decision criteria was also developed, which include clarifying decision context, establishing decision objectives, identifying, clustering 
and assessing decision criteria. The process and the decision criteria matrix together provide housebuilding organizations with a systematic approach to achieving more informed technology decisions for delivering sustainable homes and managing technological innovation to sustain competitiveness. The sub-criteria in the decision matrix are not prescriptive and should be adapted to the organizational and project context concerned, while the process of establishing criteria should be generically applicable.

\section{References}

Adams, D. and Leishman, C. (2008). Factors Affecting Housing Build-out Rates, CLG Housing Markets and Planning Analysis Expert Panel, CLG, London.

Atkinson, C., Yates, A. and Wyatt, M. (2009). Sustainability in the Built Environment: An introduction to its definition and measurement, Watford: BRE.

Ball, M. (2008). Firm size and competition: a comparison of the housebuilding industries in Australia, the United Kingdom and the USA, RICS, London.

Ball, M. (2010). The husebuilding industry: Promoting recovery in housing supply, DCLG, London.

Barlow, J. and Ozaki, R. (2005). "Building mass customised housing though innovation in the production system: lessons from Japan.” Environment and Planning A, 37, 9-20.

Barron, F. H. and Barrett, B. E. (1996). “The efficacy of SMARTER - Simple MultiAttribute Rating Technique Extended to Ranking.” Acta Psychologica, 93, 23-36.

Birkbeck, D. and Scoones, A. (2005). Prefabulous Homes: The new housebuilding agenda, Constructing Excellence, London.

Blismas, N.G. and Wakefield, R. (2009). "Drivers, constraints and the future of offsite manufacture in Australia.” Construction Innovation, 9(1), 72-83. 
Blismas, N., Pasquire, C. and Gibb, A. (2006). "Benefit evaluation for off-site production in construction.” Construction Management and Economics, 24(2), 121-30.

BRE Certification (2005). Standard for Innovative Methods of Dwelling Construction LPS 2020:2005, Issue: Version 3, BRE Certification, Watford.

Bryman, A. (2008). Social Research Methods. 3rd edn. Oxford University Press, Oxford.

Callcutt, J. (2007). The Callcutt Review of Housebuilding Delivery, DCLG, London.

Chen, Y. Okudan, G.E. and Riley, D.R. (2010). “Sustainable performance criteria for construction method selection in concrete buildings.” Automation in Construction, 19(2), 235-44.

Constructing Excellence (2004). Housing KPI Toolkit 2004, Constructing Excellence, London.

DCLG (2006). Design for Manufacture Lessons Learnt, Department for Communities and Local Government (DCLG), London.

DCLG (2007). Building a Greener Future: Policy Statement, DCLG, London.

DCLG (2010). Live Table 117: Dwelling stock: type of accommodation; Live Table 254:

Housebuilding: permanent dwellings completed, by house and flat, number of bedroom and tenure, DCLG, London.

Dodgson, J., Spackman, M., Pearman, A. and Phillips, L. (2000). Multi-Criteria Analysis: a Manual, DETR, London.

Dodgson, M., Gann, D. and Salter, A. (2008). The Management of Technological Innovation: Strategy and Practice, Oxford University Press, Oxford.

Eastman, C. M. and Sacks, R. (2008). "Relative Productivity in the AEC Industries in the United States for On-Site and Off-Site Activities.” Journal of Construction Engineering and Management, 134(7), 517-526. 
Edwards, W. (1977). "How to use multiattribute utility measurement for social decision making.” IEEE Transactions on Systems, Man, and Cybernetics, SMC-7, 326-40.

Edwards, W. and Barron, F. H. (1994). "SMARTS and SMARTER: Improved Simple Methods for Multiattribute Utility Measurement.” Organisational Behavior and Human Decision Processes, 60(3), 306-25.

Egan, J. (1998). Rethinking Construction: The Report of the Construction Task Force. London: DETR.

Gann, D.M. (2000). Building Innovation: Complex Constructs in a Changing World, Thomas Telford Publishing, London.

Gann, D. and Senker, P. (1993). "International Trends in Construction Technologies and the Future of Housebuilding.” Futures, 25(1), 53-65.

Gibb, A.G.F. (1999). Off-site Fabrication: Prefabrication, Pre-assembly and Modularisation, Whittles Publishing, Caithness.

Gibb, A.G.F. and Isack, F. (2003). "Re-engineering through pre-assembly: client expectations and drivers.” Building Research and Information, 31(2), 146-60.

Gibb, A.G.F. and Pendlebury, M.C. (2005). The CIRIA Offsite Project Toolkit. CIRIA, London.

Girmscheid, G. and Scheublin, F. (2010). New Perspective in Industrialisation in Construction: A State-of-the-Art Report, CIB Task Group 57, Zurich.

Goodier, C.I. and Gibb, A.G.F. (2007). "Future opportunities for offsite in the UK.” Construction Management and Economics, 25, 585-95.

HCA (2010). Design for Manufacture Lessons Learnt 2, Homes and Communities Agency (HCA), London. 
Hofman, E., Voordijk, H. and Halman, J. (2009). "Matching supply networks to a modular product architecture in the house-building industry.” Building Research \& Information, 37(1), 31-42.

Huang, X. and Hinze, J. (2003). “Analysis of Construction Worker Fall Accidents.” Journal of Construction Engineering and Management, 129(3), 262-271.

Idrus, A. B. and Newman, J. B. (2002). “Construction related factors influencing the choice of concrete floor systems." Construction Management and Economics, 20(1), 13-9.

Jaillon, L. and Poon, C.S. (2009). “The evolution of prefabricated residential building systems in Hong Kong: A review of the public and the private sector.” Automation in Construction, 18, 239-48.

Kadir, M.R.A., Lee, W.P., Jaafar, M.S., Sapuan, S.M. and Ali, A.A.A. (2006).

“Construction performance comparison between conventional and industrialised building systems in Malaysia.” Structural Survey, 24(5), 412-24.

Keeney, R. L. and Raiffa, H. (1976). Decisions with Multiple Objectives: Preferences and Value Trade-offs, Wiley, New York.

Kim, S., Yang, I., Yeo, M. and Kim, K. (2005). "Development of a housing performance evaluation model for multi-family residential buildings in Korea.” Building and Environment, 40, 1103-1116.

Knight Frank (2009). The Future of Residential Development, Knight Frank, London.

Larsson, B., Sundqvist, J. and Emmitt, S. (2006). “Component manufacturers’ perceptions of managing innovation.” Building Research \& Information, 34(6), 552-64.

Meikle, J. (2008). “UK housebuilding.” Building Research \& Information, 36(2), 200-2 Monjo-Carrio, J., Oteiza, I. and de Llano, J.Q. (2010). “Integrated Design and Production Decision-making Tools for Optimal Industrialisation of Housing Construction.” In 
Girmscheid, G. and Scheublin, F. (eds.) Industrialisation in Construction, CIB Task Group 57, Zurich.

Mtech Group (2007). “Directory.” Offsite 2007, Building Magazine, London, 38-54.

Mullens, M. A. and Arif, M. (2006). “Structural Insulated Panels: Impact on the Residential Construction Process.” Journal of Construction Engineering and Management, 132(7) 786-794.

NAO (2005). Using modern methods of construction to build homes more quickly and efficiently, National Audit Office (NAO), London.

NAO (2007). Homebuilding: Measuring Construction Performance, NAO, London.

Nassar, K., Thabet, W. and Beliveau, Y. (2003). “A procedure for multi-criteria selection of building assemblies.” Automation in Construction, 12(5), 543-60.

ODPM (2003). Sustainable Communities: Building for the future, Office of the Deputy Prime Minister (ODPM), London.

OFT (2008). Homebuilding in the UK: A market study, Office of Fair Trading (OFT), London.

Osmani, M. and O’Reilly, A. (2009). “Feasibility of zero carbon homes in England by 2016: A house builder’s perspective.” Building and Environment, 44, 1917-1924.

Pasquire, C. L. and Gibb, A. G. F. (2002). "Considerations for assessing the benefits of standardisation and pre-assembly in construction.” Journal of Financial Management of Property and Construction, 7(3), 151-61.

Pasquire, C.L., Gibb, A.G.F. and Blismas, N. (2005). "What should you really measure if you want to compare prefabrication with traditional construction?” Proc. IGLC-13, the International Group for Lean Construction (IGLC), Sydney, Australia, pp. 481-91.

Pan, W. (2010). "Relationships between air-tightness and its influencing factors of post2006 new-build dwellings in the UK.” Building and Environment, 45(11), 2387-99. 
Pan, W, Gibb, A.G.F. and Dainty, A.R.J. (2007). "Perspectives of housebuilders on the use of offsite Modern Methods of Construction.” Construction Management and Economics, 25(2), 183-94.

Pan, W, Gibb, A.G.F. and Dainty, A.R.J. (2008). “Leading UK housebuilders’ utilization of offsite construction methods.” Building Research \& Information, 36(1), 56-67.

Patton, M Q (2002). Qualitative Research and Evaluation Methods. 3ed. Thousand Oaks: Sage.

Prewer, J. (2005). “Thirty things to reduce or eliminate when designing for prefabrication.” In Prefabulous Homes: The new housebuilding agenda, D. Birkbeck \& A. Scoones, (eds.), Constructing Excellence, London, pp. 18-19.

Roberts, R. and Goodwin, P. (2002). "Weight Approximations in Multi-attribute Decision Models.” Journal of Multi-Criteria Decision Analysis, 11(6), 291-303.

Rogers, M. (2000). “Using Electre III to aid the choice of housing construction process within structural engineering.” Construction Management and Economics, 18(3), 33342.

Roy, R., Brown, J. and Gaze, C. (2003). "Re-engineering the construction process in the speculative house-building sector.” Construction Management and Economics, 21(2), 137-46.

Saaty, T. L. (1980). The Analytic Hierarchy Process, McGraw-Hill International, New York.

Sacks, R., Eastman, C. M. and Lee, G. (2004). “Process Model Perspectives on Management and Engineering Procedures in the Precast/Prestressed Concrete Industry.” Journal of Construction Engineering and Management, 130(2), 206-215.

Silverman, D. (2005). Doing Qualitative Research: A practical handbook, 2nd edn. Sage, London. 
Soetanto, R., Dainty, A. R. J., Glass, J. and Price, A. D. F. (2004). “Criteria for assessing the potential performance of hybrid concrete structural frame.” Engineering, Construction and Architectural Management, 11(6), 414-25.

Song, J., Fagerlund, W. R., Haas, C. T., Tatum, C. B. and Vanegas, J. A. (2004). “Considering Prework on Industrial Projects.” Journal of Construction Engineering and Management, 131(6), 723-733.

Stoy, C., Pollalis, S. and Schalcher, H. (2008). “Drivers for Cost Estimating in Early Design: Case Study of Residential Construction.” Journal of Construction Engineering and Management, 134(1), 32-39.

Tam, C.M., Deng, Z.M. and Zeng, S.X. (2002). "Evaluation of construction methods and performance for high rise public housing construction in Hong Kong.” Building and Environment, 37, 983-991.

Tam, V.W.Y., Tam, C.M., Zeng, S.X. and Ng, W.C.Y. (2007). “Towards adoption of prefabrication in construction.” Building and Environment, 42, 3642-3654.

Tatum, C. B., Vanegas, J. A. and Williams, J. M. (1987). Constructability improvement using prefabrication, preassembly, and modularization, Construction Industry Institute, Austin, Tex.

TSO (2010). Spending Review 2010, The Stationery Office (TSO), Norwich.

Venables, T. and Courtney, R. (2004). Modern methods of construction in Germanyplaying the off-site rule. Report of a DTI Global Watch Mission. DTI: London.

Wellings, F. (2006). Private Housebuilding Annual 2006, Troubadour Publishing, London. Wells, J. (1993). “Appropriate building technologies: An appraisal based on case studies of building projects in Senegal and Kenya.” Construction Management and Economics, 11, 203-216. 
Wong, J. and Li, H. (2006). "Development of a conceptual model for the selection of intelligent building systems.” Building and Environment, 41, 1106-1123.

Wood, G.D., and R.C.T. Ellis. (2005). "Main contractor experiences of partnering relationships on UK construction projects.” Construction Management and Economics 23: 317-25.

Yin, R.K. (2003). Case Study Research: Design and Methods. $3^{\text {rd }}$ edn. Thousand Oaks: Sage. 
Table 1 Details of participating organisations

\begin{tabular}{|c|c|c|c|}
\hline Housebuilder & Unit completions $^{\text {a }}$ & Turnover $(£ m)^{a}$ & Participants \\
\hline Company A & 1,594 & 358 & $\begin{array}{l}\text { Group Technical Manager, Architect }{ }^{\mathrm{c}} \text {, } \\
\text { Estimating Director }^{\mathrm{d}} \text {, Structural } \\
\text { Engineer }^{\mathrm{e}}\end{array}$ \\
\hline Company B & 8,178 & 1,647 & Head of R\&D ${ }^{f}$, Production Director \\
\hline Company C & 7,001 & 1,178 & Group Product Development Manager \\
\hline Company D & 2,702 & 521 & R\&D Director \\
\hline Company E & 1,100 & 285.7 & $\begin{array}{l}\text { Managing Director, Director of } \\
\text { Innovation }\end{array}$ \\
\hline Company F & 1,215 & 225.5 & R\&D Manager \\
\hline Total (Company A-F) & 21,790 & $4,215.2$ & - \\
\hline UK industry as a whole & $206,620^{b}$ & - & - \\
\hline Percentage & $10.55 \%$ & - & - \\
\hline
\end{tabular}

a Source: Wellings (2006)

${ }^{\mathrm{b}}$ Source: DCLG: Live Table 209

${ }^{\mathrm{c}}$ The Architect by profession, who was a business consultant seconded to the company, acting as change agent.

$\mathrm{d}$ The Estimating Director was leading the cost analysis of offsite in comparison with conventional methods in the company.

e The Structural Engineer, who was an external consultant of the company for exploring offsite utilisation.

${ }^{\mathrm{f}} \mathrm{R} \& \mathrm{D}$ - Research \& Development 
Table 2 Building types and systems ${ }^{\mathrm{a}}$ included in the study

\begin{tabular}{|c|c|c|c|c|c|c|}
\hline Company & A & $\mathrm{B}$ & $\mathrm{C}$ & $\mathrm{D}$ & $\mathrm{E}$ & $\mathrm{F}$ \\
\hline \multicolumn{7}{|l|}{ Building types } \\
\hline Semi-detached & & & $\sqrt{ }$ & $\sqrt{ }$ & & $\sqrt{ }$ \\
\hline Terraced & & $\sqrt{ }$ & $\sqrt{ }$ & & & $\sqrt{ }$ \\
\hline Low-rise apartment buildings ${ }^{\text {b }}$ & $\sqrt{ }$ & & & & $\sqrt{ }$ & $\sqrt{ }$ \\
\hline \multicolumn{7}{|l|}{ Building systems } \\
\hline Traditional brick \& block & $\sqrt{ }$ & $\sqrt{ }$ & $\sqrt{ }$ & $\sqrt{ }$ & $\sqrt{ }$ & $\sqrt{ }$ \\
\hline Thin-joint masonry & & & & $\sqrt{ }$ & & \\
\hline Open timber panel & $\sqrt{ }$ & $\sqrt{ }$ & $\sqrt{ }$ & $\sqrt{ }$ & $\sqrt{ }$ & $\sqrt{ }$ \\
\hline Closed timber panel & & & $\sqrt{ }$ & & $\sqrt{ }$ & \\
\hline Insitu reinforced concrete frame & $\sqrt{ }$ & & & & & \\
\hline Precast concrete (PCC) crosswall & $\sqrt{ }$ & & & & & \\
\hline Steel frame with PCC floors & $\sqrt{ }$ & & & & & \\
\hline Steel framed modular & & & & & $\sqrt{ }$ & \\
\hline
\end{tabular}

a The included building types were most regularly-built by the companies and were applicable to building system selection. The building systems were explored and/or utilised in the companies.

${ }^{\mathrm{b}} \mathrm{Up}$ to five storeys as considered by the participants. 
Table 3 Decision criteria and weights for building system selection

\begin{tabular}{|c|c|c|c|c|c|c|c|c|c|}
\hline & & Company & $\mathrm{A}$ & B & $\mathrm{C}$ & $\mathrm{D}$ & $\mathrm{E}$ & $\mathrm{F}$ & $\mathrm{F}$ \\
\hline Objectives & Criteria & Sub-criteria & Flats & Houses & Houses & Houses & Flats & Houses & Flats \\
\hline \multirow[t]{12}{*}{ Cost } & Build cost of the system & & 0.082 & 0.100 & 0.074 & 0.040 & 0.028 & 0.176 & 0.147 \\
\hline & Cost certainty & & 0.082 & 0.100 & & 0.032 & 0.025 & 0.071 & 0.059 \\
\hline & Design cost & & & 0.100 & & 0.032 & 0.020 & & \\
\hline & $\begin{array}{l}\text { Impacts on the costs of } \\
\text { interfacing systems }\end{array}$ & $\begin{array}{l}\text { Transfer structure (e.g. to } \\
\text { car-park) }\end{array}$ & 0.003 & 0.020 & & 0.006 & 0.004 & 0.026 & 0.022 \\
\hline & & Interface with cladding & 0.056 & 0.020 & & 0.006 & 0.004 & 0.026 & 0.022 \\
\hline & & $\begin{array}{l}\text { Additional flooring/ stairs } \\
\text { treatment? }\end{array}$ & 0.021 & 0.020 & & 0.006 & 0.004 & 0.026 & 0.022 \\
\hline & & $\begin{array}{l}\text { Additional wall } \\
\text { treatment? }\end{array}$ & 0.013 & 0.020 & & 0.006 & 0.004 & 0.026 & 0.022 \\
\hline & & $\begin{array}{l}\text { Additional roof } \\
\text { treatment? } \\
\text { Balcony options }\end{array}$ & 0.008 & 0.020 & & 0.006 & 0.004 & 0.026 & 0.022 \\
\hline & $\begin{array}{l}\text { Impacts on the costs of } \\
\text { related items }\end{array}$ & $\begin{array}{l}\text { Lift equipment \& } \\
\text { efficiency }\end{array}$ & 0.027 & 0.050 & 0.034 & 0.016 & 0.012 & 0.044 & 0.037 \\
\hline & & $\begin{array}{l}\text { Scaffolding (external) } \\
\text { required? }\end{array}$ & 0.027 & 0.050 & 0.034 & 0.016 & 0.012 & 0.044 & 0.037 \\
\hline & & $\begin{array}{l}\text { Changes required for site } \\
\text { work }\end{array}$ & & & & & & 0.044 & 0.037 \\
\hline & Maintenance costs & & 0.020 & 0.100 & 0.067 & 0.032 & 0.027 & 0.088 & 0.074 \\
\hline \multirow[t]{5}{*}{ Time } & Design cut-off & & & 0.020 & & 0.040 & 0.017 & 0.010 & 0.038 \\
\hline & Design lead in & & 0.006 & 0.020 & 0.089 & 0.060 & 0.017 & 0.010 & 0.038 \\
\hline & $\begin{array}{l}\text { Speed to construct / floor } \\
\text { cycle }\end{array}$ & & 0.037 & 0.020 & 0.089 & 0.060 & 0.051 & 0.010 & 0.038 \\
\hline & Time certainty & & 0.037 & 0.020 & & 0.040 & 0.086 & 0.010 & 0.038 \\
\hline & $\begin{array}{l}\text { Impact on the following } \\
\text { trades }\end{array}$ & & & 0.020 & & & & & \\
\hline \multirow[t]{10}{*}{ Quality } & $\begin{array}{l}\text { Compliance with Building } \\
\text { Regulations }\end{array}$ & Structural Part A & 0.000 & 0.008 & 0.008 & & 0.005 & 0.005 & 0.003 \\
\hline & & Fire safety Part B & 0.000 & 0.008 & 0.008 & & 0.005 & 0.005 & 0.003 \\
\hline & & Acoustic Part E & 0.002 & 0.008 & 0.008 & & 0.005 & 0.005 & 0.003 \\
\hline & & Ventilation Part F & 0.001 & 0.008 & 0.008 & & 0.005 & 0.005 & 0.003 \\
\hline & & Thermal Part L & 0.000 & 0.008 & 0.008 & & 0.005 & 0.005 & 0.003 \\
\hline & $\begin{array}{l}\text { Build control during } \\
\text { construction }\end{array}$ & & & & & & 0.026 & & \\
\hline & Defects (at handover) & & 0.044 & 0.040 & 0.039 & 0.038 & 0.034 & 0.029 & 0.017 \\
\hline & $\begin{array}{l}\text { Customer acceptance and } \\
\text { satisfaction }\end{array}$ & & 0.011 & 0.040 & 0.039 & 0.038 & 0.038 & 0.036 & 0.021 \\
\hline & $\begin{array}{l}\text { Design flexibility } \\
\text { (compatibility \& } \\
\text { adaptability) }\end{array}$ & & & 0.040 & 0.039 & 0.038 & 0.030 & 0.029 & 0.017 \\
\hline & $\begin{array}{l}\text { Performance throughout } \\
\text { the lifecycle of housing }\end{array}$ & & 0.011 & 0.040 & 0.039 & 0.038 & 0.004 & 0.029 & 0.017 \\
\hline $\begin{array}{l}\text { Health \& } \\
\text { Safety }\end{array}$ & Health \& Safety risks & & 0.039 & & & & 0.154 & 0.010 & 0.060 \\
\hline \multirow[t]{7}{*}{$\begin{array}{l}\text { Sustainabili } \\
\text { ty }\end{array}$} & $\begin{array}{l}\text { Energy efficiency } \\
\text { (conservation of fuel and } \\
\text { power) }\end{array}$ & & 0.004 & & 0.042 & 0.030 & 0.029 & 0.020 & 0.018 \\
\hline & $\begin{array}{l}\text { Site waste management } \\
\text { (during construction) }\end{array}$ & & 0.028 & & 0.038 & 0.030 & 0.026 & 0.016 & 0.015 \\
\hline & Use of materials & & & & 0.033 & 0.030 & 0.017 & 0.016 & 0.015 \\
\hline & Lifetime Homes & & & & & 0.030 & 0.025 & 0.016 & 0.015 \\
\hline & $\begin{array}{l}\text { EcoHomes / Code for } \\
\text { Sustainable Homes }\end{array}$ & & 0.007 & & & & & 0.005 & 0.003 \\
\hline & Day-lighting & & & & 0.025 & 0.030 & 0.023 & 0.020 & 0.018 \\
\hline & Orientation of house & & & & 0.029 & & & & \\
\hline \multirow[t]{4}{*}{ Process } & $\begin{array}{l}\text { Design standardisation \& } \\
\text { repeatability }\end{array}$ & & 0.094 & 0.013 & 0.044 & 0.044 & 0.021 & 0.014 & 0.014 \\
\hline & Design flexibility & & 0.001 & & & & & & \\
\hline & Logistics & $\begin{array}{l}\text { Transportation from } \\
\text { factory to site }\end{array}$ & 0.013 & 0.004 & 0.013 & 0.014 & 0.007 & 0.003 & 0.003 \\
\hline & & Transportation within the & 0.004 & 0.004 & 0.013 & 0.011 & 0.007 & 0.003 & 0.003 \\
\hline
\end{tabular}




\begin{tabular}{|c|c|c|c|c|c|c|c|c|c|}
\hline & & Company & A & B & $\mathrm{C}$ & $\mathrm{D}$ & $\mathrm{E}$ & F & F \\
\hline Objectives & Criteria & Sub-criteria & Flats & Houses & Houses & Houses & Flats & Houses & Flats \\
\hline & & site & & & & & & & \\
\hline & & Site storage required & 0.019 & 0.004 & 0.013 & 0.011 & 0.007 & 0.003 & 0.003 \\
\hline & & $\begin{array}{l}\text { Storage required in } \\
\text { factory }\end{array}$ & & & & & & 0.003 & 0.003 \\
\hline & $\begin{array}{l}\text { Ease of site coordination } \\
\text { (e.g. M\&E) }\end{array}$ & & & 0.013 & 0.040 & 0.035 & 0.021 & 0.011 & 0.011 \\
\hline & Site access and planning & & & & & & & 0.011 & 0.011 \\
\hline & $\begin{array}{l}\text { Previous experience of the } \\
\text { housebuilder }\end{array}$ & & 0.094 & 0.013 & 0.033 & 0.035 & 0.021 & 0.011 & 0.011 \\
\hline \multirow{9}{*}{$\begin{array}{l}\text { Procuremen } \\
\mathrm{t}\end{array}$} & Suitability for in-house & Historical method & & 0.004 & & 0.010 & & & \\
\hline & build & adopted by the company & & & & & & & \\
\hline & & $\begin{array}{l}\text { Possibility of the method } \\
\text { being managed by in } \\
\text { house build team }\end{array}$ & & 0.004 & & 0.010 & & & \\
\hline & Height limitations & & & 0.007 & & 0.015 & & & \\
\hline & $\begin{array}{l}\text { Market availability of the } \\
\text { system }\end{array}$ & & & 0.007 & 0.025 & 0.024 & 0.025 & 0.012 & 0.014 \\
\hline & Manufacturing capacity & & 0.033 & 0.007 & 0.028 & 0.024 & 0.020 & 0.012 & 0.014 \\
\hline & $\begin{array}{l}\text { Manufacturer/ supplier } \\
\text { competency }\end{array}$ & & 0.033 & 0.007 & 0.028 & 0.024 & 0.020 & 0.012 & 0.014 \\
\hline & Contractual risk & & & 0.007 & & 0.024 & & & \\
\hline & $\begin{array}{l}\text { Possibility for use in future } \\
\text { projects }\end{array}$ & & 0.007 & 0.007 & 0.023 & 0.019 & 0.020 & 0.015 & 0.018 \\
\hline Regulatory & How easy to obtain & & 0.008 & & & & 0.025 & & \\
\hline \& Statutory & planning permission? & & & & & & & & \\
\hline \multirow[t]{5}{*}{ Acceptance } & $\begin{array}{l}\text { Financial market's } \\
\text { acceptance }\end{array}$ & & 0.068 & & & & 0.021 & & \\
\hline & $\begin{array}{l}\text { Insurance industry's } \\
\text { acceptance }\end{array}$ & Lenders' acceptance & 0.014 & & & & 0.007 & & \\
\hline & & Insurers' acceptance & 0.014 & & & & 0.007 & & \\
\hline & & $\begin{array}{l}\text { Warranty providers' } \\
\text { acceptance }\end{array}$ & 0.014 & & & & 0.007 & & \\
\hline & Legal issues & & 0.018 & & & & 0.019 & & \\
\hline Overall & & & 1.000 & 1.000 & 1.000 & 1.000 & 1.000 & 1.000 & 1.000 \\
\hline
\end{tabular}

Notes: Company A's weights from the group (denoted in Table 4), modestly correlated with weights from its Technical Manager $(r=0.3, p=0.06$, 2-tailed); 
Table 4 Correlations between weights of detailed-level criteria

\begin{tabular}{|c|c|c|c|c|c|c|c|c|}
\hline \multicolumn{5}{|c|}{ Houses } & \multicolumn{4}{|c|}{ Apartments } \\
\hline Company & B & $\mathrm{C}$ & $\mathrm{D}$ & $\mathrm{F}$ & & A & $\mathrm{E}$ & $\mathrm{F}$ \\
\hline \multirow[t]{2}{*}{ B } & 1 (39) & $.578^{* *}(.002)$ & $.287(.105)$ & $.882^{* *}(.000)$ & A & $1(40)$ & .259 (.116) & $.464^{* *}(.007)$ \\
\hline & & (25) & (33) & (33) & & & (38) & (33) \\
\hline \multirow[t]{2}{*}{$\mathrm{C}$} & & $1(30)$ & $.848^{* *}(.000)$ & $.499^{* *}(.006)$ & E & & $1(47)$ & $.359^{*}(.025)$ \\
\hline & & & (24) & (29) & & & & (39) \\
\hline \multirow[t]{2}{*}{$\mathrm{D}$} & & & $1(38)$ & $.098(.588)$ & $\mathrm{F}$ & & & $1(43)$ \\
\hline & & & & (33) & & & & \\
\hline $\mathrm{F}$ & & & & $1(43)$ & & & & \\
\hline
\end{tabular}

Note: r (p) (n); ** Correlation significant at the 0.01 level; * Correlation significant at the 0.05 level; 2-tailed. 


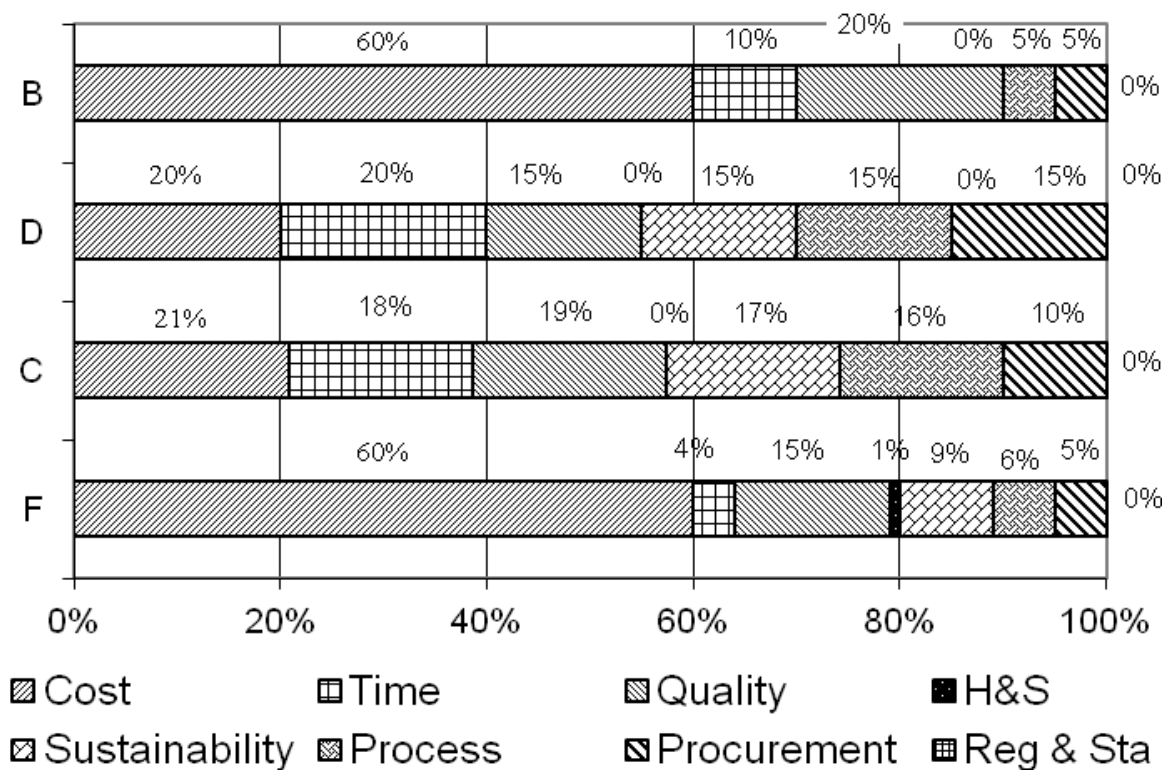

Figure 1 The weights of the main decision criteria for houses

Notes:

B, C, D \& F represent Companies B, C, D \& F;

'Reg \& Sta' stands for Regulatory \& Statutory Acceptance;

'H\&S' and 'Reg \& Sta' criteria were weighed zero or very low (1\%) as they were considered compulsory, hence offering no decision tradeoff. 


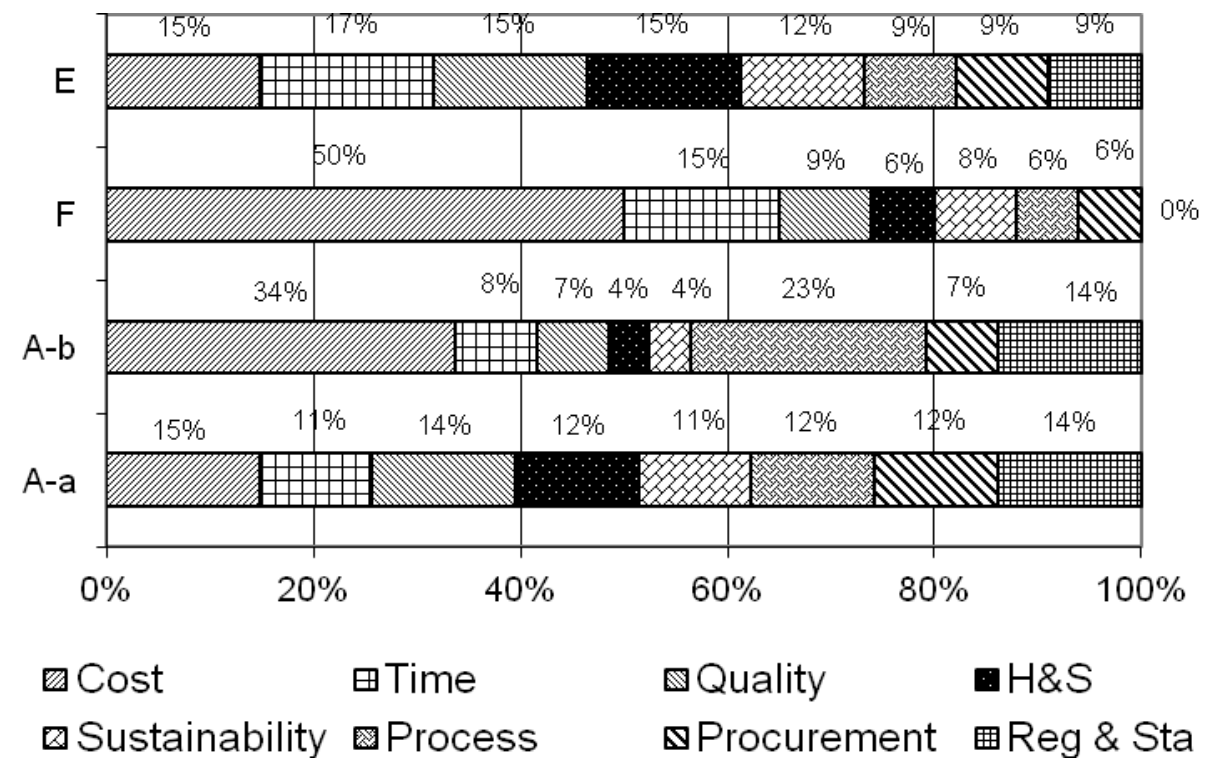

Figure 2 The weights of the main decision criteria for low-rise apartment buildings

Notes:

A, E \& F represent Companies A, E and F;

A-a represents the weights from the Group Technical Manager of Company A;

A-b represents the group-agreed weights of Company A;

'Reg \& Sta' stands for Regulatory \& Statutory Acceptance. 